\title{
Forest property taxation in New Brunswick: A comment
}

\author{
by B. A. Cook ${ }^{1}$
}

Non-industrial private forest (NIPF) land comprises approximately one-third of the forested area of New Brunswick. Harvesting activity on NIPFs has been facilitated through the establishment of forest marketing boards for primary products and legislation which requires that NIPF land be the principal source of supply for Crown licensees. Management activity on NIPFs has been encouraged through a policy of grant assistance and technical aid. The property tax structure does not necessarily reinforce these policies. Here, theoretical considerations of forest property tax structure are introduced and an examination of forest property taxation of New Brunswick NIPF lands is undertaken.
Les boisés privés non-industriels (BPNI) totalisent approximativement un tiers de la superficie forestière du NouveauBrunswick. Les activités de récolte sur les BPNI ont été facilitées par la mise en place de régies de mise en marché des produits primaires et d'une législation qui exige que les terrains BPNI soient la principale source d'approvisionnement pour les détenteurs de permis provinciaux. Les activités d'aménagement sur les BPNI ont été encouragés par une politique d'assistance monétaire et d'aide technique. La structure des impôts fonciers ne renforce pas nécessairement ces politiques. Cet exposé introduit des considérations théoriques sur la structure des impôts fonciers et un examen du système de taxation des propriétés forestières pour les BPNI du Nouveau-Brunswick est effectué.

\section{Introduction}

It has recently been suggested that property tax policies should be strengthened to favour managed woodlots (Blouin 1988). A strong case can be made for such an approach in the province of New Brunswick (NB). ${ }^{2}$ The province faces an impending woodsupply problem which is the result of an age-structure imbalance involving too many old trees and not enough middle-aged ones (Watson 1984). The shortage foreshadows a transition from the mining of the forest inventory to the cropping of regenerated timber.

Extensive steps have been taken to upgrade the management of industrial woodlands in the province (Watson 1984). However, NIPF land, which comprises approximately one third of the forest area of NB and is critical to maintaining current industrial output, has not been extensively managed. ${ }^{3}$ Policies to encourage management activity on NIPF lands are in place through technical aid and grant assistance funded through Canada/NB Forest Renewal Agreements. Policies to encourage harvesting are aided by seven regional marketing boards which organize the delivery of wood from NIPF land to industry. Such policies might be made more effective were they related to tax policy.

The current property tax system provides no incentive to engage in forest management. At the present time, assessment of land is performed by the Province under the Assessment Act and taxes are imposed provincially under the Real Property Tax Act (NB 1978). This paper examines forest property taxation of NIPF lands in NB. It proceeds as follows: theoretical considerations of forest property tax structure are introduced; current forest property tax policy in NB is described; alternative forest property tax regimes are discussed; and concluding comments are made.

\footnotetext{
'Associate Professor, Department of Economics, University of New Brunswick, Box 4400, Fredericton, New Brunswick E3B 5A3.

${ }^{2}$ Arseneault (1983) suggested the provincial government should consider favorable property tax provisions for private nonindustrial wooded properties. ${ }^{3} \mathrm{NIPFs}$ are defined to be woodlots between 10 and 4000 hectares belonging to individuals, organizations, and corporations not operating a processing facility.
}

\section{Forest Property Taxation}

Equity, or fairness, is a primary consideration of any tax policy. Two principles of equity have been advanced in the tax literature - the benefit principle and the ability to pay principle (Musgrave and Musgrave 1984). Under the benefit principle, taxes are levied according to the benefits received from the tax expenditures. Taxation according to ability to pay involves questions of treating equals equally (horizontal equity) and the distribution of tax burdens among people with different abilities to pay (vertical equity). ${ }^{4}$ Neutrality is also a consideration as taxes can distort market decisions thereby creating inefficiencies. A perfectly neutral tax does not affect decision-making because the tax cannot be avoided by adjusting behaviour. Most taxes are generally nonneutral to varying degrees. ${ }^{5}$ The policy challenge lies in implementing a tax which minimizes inefficiencies and promotes desired policy goals.

Forest property taxes can be categorized as either ad valorem or excise (Society of American Foresters 1980). The ad valorem tax is based on the assessed value of the property while the exercise tax is levied on the harvest itself. The forest economics literature discusses these taxes extensively and only a brief overview is given here. ${ }^{6}$

\section{Ad valorem Taxes}

The ad valorem tax depends on the capital value of the property. This has typically been defined so as to include in its base the value of the timber on the land as well as the value of the land. ${ }^{7}$ Capital values are usually determined by

\footnotetext{
${ }^{4} \mathrm{An}$ example of taxation according to benefits received is found with tol highways and bridges. Alternatively, the progressively higher tax payments associated with higher incomes reflect the ability to pay principle applied to income taxes.

${ }^{5}$ The only perfectly neutral tax appears to be a head tax (lump sum tax) on living persons as it cannot be avoided. Otherwise, taxes have various impacts on consumption and production decisions.

${ }^{6} \mathrm{~A}$ more detailed theoretical examination of the forest property tax can be found, for example, in Klemperer (1978, 1982), Gaffney (1979), Jackson (1980), Stier and Chang (1983), or Boyd (1986). Discussion of Canadian taxation may be found in Boulter (1984) and Canadian Forestry Association (1983).

${ }^{7}$ This is labelled an 'unmodified property tax' in the forestry literature.
} 
market sales comparison. A modification of this approach is the site value (or productivity) tax. Here, the timberland is taxed according to its ability to produce net income so that only the land is taxed (with the timber standing on it exempted). Income capitalization procedures replace market value procedures in this instance. The site value is derived from the discounted net value of all future harvests. These site value taxes are collected annually, but the payments do not grow with the value of the standing timber as is the case with an unmodified ad valorem tax. However, administrative difficulties in evaluating the discounted stream of future earnings may arise in the property assessment (Anglin 1991). In such circumstances, some proxy (e.g., recent sales of comparable property) may be utilized.

Klemperer (1982) analyzes the impact of the ad valorem and site value taxes on capitalized property values. The ad valorem tax is shown to produce a heavier burden on land with longer rotations as well as land with a high cost-toincome ratio. Alternatively, a site value tax is found to be neutral in terms of these effects. However, he suggests that the site value tax violates equity criteria because improvements are taxed in other uses of property while this would not be the case with forest property. In effect, ownership of forest property would be encouraged.

Mills (1981) demonstrates the possibility of changes in land use with either ad valorem or site value taxes because projects with earlier pay-offs may be preferred. In a forestry context, this means the conversion of forest land into recreational and urban use. Property is most commonly appraised at the value associated with highest and best use. Urban land use values are generally greater than agricultural and forestland values and, as development proceeds outward from urban areas over time, land values and property taxes increase. Agricultural and forest landowners then have an incentive to sell their land to developers. In order to prevent this turnover, current use taxation may be adopted when open land and green space are desired, particularly in urban fringe areas. This means taxes remain unchanged for agriculture and forestlands at the margin of urban development. In concert with Mills' assessment, Boyd and Hyde (1989) indicate that such current use taxes only delay eventual development rather than halt it.

\section{Excise Taxes}

An alternative to the annual ad valorem tax is an excise (or yield) tax levied at the time of harvest. Its purpose is to substitute a single timber tax at the time of harvest for the annual tax on timber. Levied in lieu of a property tax on standing timber, it may be accompanied by a separate annual tax on the land. Payment is generally some percentage of stumpage. Yield tax revenues fluctuate considerably from year to year according to harvest and/or stumpage variations. This tax is generally easier to administer than an ad valorem tax but it has been shown (e.g., Jackson 1980, Chang 1982) that the effect is to lengthen the rotation and discourage restocking. Governments find the yearly variation in excise revenues less appealing than the assured steady stream of payments derived from the ad valorem property tax. Gamponia and Mendelsohn (1987) show, however, that when property and yield tax rates applied to lobolly pine and Douglas fir are defined so as to earn equivalent revenue, yield taxes produce less rotation age distortion than unmodified property taxes. (An analysis of this type for the major commercial species in NB might prove useful to policymakers.)

\section{New Brunswick Forest Property Tax}

Property taxation had considerable negative impact on forest management in New Brunswick until 1967. The unmodified ad valorem tax was utilized with woodlands assessed at the value of the land plus the standing crop. It was not uncommon for woodlands to be cleared primarily to avoid excessive taxes (Tweedale 1974). An extensive reform of property taxation and municipal finance was introduced in 1967. Since then, the value of the standing crop has not entered into woodland assessment as a "modified" assessment practice has instead provided for a fixed assessment of forestland.

NB and Prince Edward Island are the only provinces imposing a province-wide property tax (Perry 1990). Municipalities and local service districts also impose taxes in NB. Under the Assessment Act, real property is classified as residential or non-residential and assessed according to its highest and best use, with reassessments performed at least every five years. Residential property is taxed at a lower rate than non-residential property. Both freehold timberland and farm woodlots are included in the definition of residential property. Once classified, property that has an area of ten hectares or more is assessed as freehold timberland or farm woodlot under section 16(2) of the Act. Under subsections $17(2)$ and 17(3), freehold timberland is assessed at $\$ 80$ per hectare and farm woodlots at their real and true value or a value that realizes a tax of $\$ 0.80$ per hectare per year, whichever is less. All freehold timberland is taxed at the provincial rate of $1.5 \%$. A municipal tax is also paid but in remote areas, it is minor. While it varies according to location, it is always less than $0.5 \%$ (NB Department of Municipal Affairs personal communication).

There are no specific definitions given for the classification of freehold timberland or farm woodlots under the Assessment Act as "highest and best use" is the criterion used. Hence property location and recreational potential play a major role in the assessment. For example, forest property fronting on rivers and lakes is not classified as freehold timberland in its entirety because a strip of the water frontage is assessed at a higher value due to recreation potential. As well, forest property in urban and urban fringe areas is assessed according to its development potential.

As currently structured, the influence of property tax incentives on timber production from NIPFs is minimal. At a nominal tax rate of $1.5 \%$, annual provincial woodlot property taxes are $\$ 1.20$ per hectare. The market value ranges from $\$ 125$ to $\$ 1225$ per hectare (NB Federation of Woodlot Owners personal communication). The $\$ 80$ assessed value is thus between $65 \%$ and $6.5 \%$ of the market value. This means the effective tax rate, ranging between $0.975 \%$ and $0.0975 \%$, is significantly less than the $1.5 \%$ nominal rate. The value of the standing timber is untaxed as there is no form of excise tax and the flat $\$ 80$ assessment makes no allowance for productivity variation. There is no tax advantage to managed woodlots under this property tax regime. Instead, the tax appears designed to favour industrial private ownership which comprises approximately $18 \%$ of NB forestland (Department of Natural Resources and Energy Annual Reports). 


\section{Discussion}

Forest property taxation in North America is highly variable and it is useful to describe various practices in order to place the NB policy in perspective. In Canada, there is a broad range of practice but five provinces appear to have a property tax structure designed to favor managed woodlots (Reed 1988): British Columbia owners who manage their forest land pay property tax at one half the rate of those who do not manage; Ontario rebates one half the property tax for properties qualifying as managed forestland; Quebec has an assessment ceiling of $\$ 325$ per hectare, frozen 30-year assessments for managed forestland and a maximum tax rate of $2 \%$; Newfoundland provides a preferential rate for managed forest property with the assessment based on a capitalized income stream; and, Nova Scotia exempts from property taxation that forest property which is used (or intended to be used) for forestry purposes.

In the United States, tax legislation is the most extensive state method used to encourage management of NIPFs (Meeks 1982). Forty-two states offer tax incentives for managed forest property as follows: twenty-two states have adopted use valuation of land; eleven states have low fixed assessment rates; five states relate assessment directly to productivity; and, four states offer long range exemption from property taxes.

NIPFs constitute 1.4 million hectares of land area and represent approximately one-third of NB forestland (Department of Natural Resources and Energy Annual Reports). A series of federal/provincial forestry agreements have provided funds for the promotion of private woodlot management (NB 1989). The first forestry subsidiary agreement, signed in 1974 and lasting six years, allocated approximately $10 \%$ of its $\$ 61$ million total directly to NIPF programs. The second agreement (1980-1984) provided a total of \$37.5 million with approximately $15 \%$ targeted to NIPFs. The third agreement (1984-1989) earmarked approximately $18 \%$ of its $\$ 77$ million total to NIPFs. The most recent agreement (1989-1993) designates 33\% of its \$81 million total to NIPFs. In sum, at least $\$ 56$ million has been provided for private woodlot management since 1974. NIPFs have not generated (property) tax revenues in concert with the benefits (tax expenditures) received in recent years. ${ }^{8}$

Private owners generally have diverse reasons for holding forestland. Owners who appear to be underproducing may, in fact, be acting rationally (Clements and Jamnick 1990). ${ }^{9}$ Extending this consideration, Boyd (1984) concludes that, if the costs are similar, a government policy which relies more heavily on the dissemination of technological and market information is likely to be a better means of increasing timber supply than a policy involving large scale reforestation subsidies. An assessment of the current NB policy of subsidization and technical assistance similar to that undertaken by Boyd (1984) is a potential avenue of future research.

\section{Conclusions}

NIPFs are currently viewed as the major source of supply for NB's wood processing sector. Owners are being

\footnotetext{
${ }^{8}$ Between 1967 and 1983 , assessments were less than $\$ 80$ per hectare.

${ }^{9}$ Non-timber benefits such as recreation, erosion and flood control, wildlife migration, and aesthetic effects may play some role in the decision not to harvest.
}

encouraged to better manage their property through financial incentives. The financial assistance for management activities is on a "first come, first served" basis. However, there is scope for adjusting forest property tax on NIPFs in $\mathrm{NB}$ in order to encourage management. Current practice is to levy the same property tax on managers and non-managers alike. But the non-neutrality potential of the property tax could be utilized to promote management via tax incentives for those who manage or tax penalties for those who do not. ${ }^{10}$ Problems related to the allocation of funds for management assistance would be tempered by this approach.

As indicated earlier, various approaches to property taxation on NIPFs are possible. From the point of view of the taxing authorities, the property tax structure should be simple to administer and allow for the prediction of tax revenues with some degree of certainty. From the point of view of property owners, the structure should be equitable and the tax burden no more onerous than that accruing with other assets. From a policy perspective, the inherent non-neutrality of the property tax should be used to promote management. The NB government currently treats only the first of these considerations and should use the property tax structure to promote management. While the specification of such a structure is beyond the scope of this paper, it is an important research topic and should be considered along with other research issues identified here.

\section{References}

Anglyn, W.T. 1991. Timber assessment procedures - a critical analysis. Apprais. J. April: 205-211.

Arseneault, F. 1983. Private woodlots: what does the future hold? Fredericton: Report of the New Brunswick Private Woodlot Resources Study. 119 pp.

Blouin, G. (ed.) 1988. From the forgotten forest to the front-line forest. Proceedings of the National Woodlot Owner's Forum. Fredericton, N.B. 33 pp.

Boulter, D. 1984. Taxation and the forestry sector in Canada. Ottawa: Agriculture Canada, Canadian Forestry Service Information Report E-X-33. 113 pp.

Boyd, R. 1984. Government support of nonindustrial production: the case of private forests. South. Econ. J. 51: 89-107.

Boyd, R. 1986. Forest taxation: current issues and future research. Research Note SE-338. Durham: U.S. Department of Agriculture, Forest Service, Southeastern Forest Experiment Station. 14 pp. Boyd, R. and W. Hyde. 1989. Forestry sector intervention: the impacts of public regulation on social welfare. Ames: Iowa State University Press. 295 pp.

Canadian Forestry Association. 1983. Taxation and private land forests and woodlots in Canada. Ottawa: Environment Canada, Canadian Forestry Service. $55 \mathrm{pp}$.

Chang, S. 1982. An economic analysis of forest taxation's impact on optimal rotation age. Land Econ. 58: 310-324.

Clements, S. and M. Jamnick. 1990. Some considerations in modelling private woodlot timber supply. For. Chron. 66(1): 41-44. Gaffney, M. 1979. Taxation on yield, property, income and site: effects on forest resources and management. Working paper 39. Riverside: University of California, Department of Economics. Gamponia, V. and R. Mendelsohn. 1987. The economic efficiency of forestry taxes. For. Sci. 33(2): 367-378.

Jackson, D. 1980. The microeconomics of the timber industry. Boulder: Westview Press. 300 pp.

\footnotetext{
${ }^{10}$ The tax adjustments would have to be considered in light of administrative constraints.
} 
Klemperer, W. D. 1982. An analysis of selected property tax exemptions for timber. Land Econ. 58: 293-304.

Klemperer, W. D. 1978. An analysis of forest tax equity guides. For. Sci. 24(3): 318-326.

Mills, D. 1981. The non-neutrality of land value taxation. Nat. Tax J. 34: 125-130.

Musgrave, R. and P., Musgrave. 1984. Public finance in theory and practice. 4th edition. Singapore: McGraw Hill. 824 pp.

New Brunswick. 1978. Assessment Act. Fredericton.

New Brunswick. 1978. Real Property Tax Act. Fredericton.

New Brunswick. 1989. Canada/New Brunswick Co-operation

Agreement on Forest Development. Fredericton. 34 pp.

New Brunswick, Department of Natural Resources and Energy.

Annual reports. Fredericton.
Reed, F.L.C. 1988. The forgotten forest: a new policy framework for the small private forests in Canada. Working draft presented at the National Woodlot Owners Forum. Fredericton, N.B.

Perry, J.H. 1990. Taxation in Canada. 5th ed. Toronto: Canadian Tax Foundation, Canadian Tax Paper 89. 331 pp.

Society of American Foresters. 1980. Forest taxation. J. For. 78(7): 409-416.

Stier, J. and S. Chang. 1983. Land use implications of the ad valorem property tax: the role of tax incidence. For. Sci. 29(4): 702-712.

Tweedale, R.E. 1974. Report of the Forest Resources Study. Fredericton. 362 pp.

Watson, R. 1984. New Brunswick's forest policy - facing the future. For. Chron. 64(2): 71-74.

\section{Membership Dues 1992-1993}

\section{Active Membership}

1 st and 2 nd year after graduation

(grad 1992, grad 1991) *(\$2.49 G.S.T. inc.)

$\$ 86.00$

Other new members for first year $*(\$ 2.49$ G.S.T. inc.)

Married or equivalent

second member only *(\$2.49 G.S.T. inc.)

All other active members $*(\$ 2.49$ G.S.T. inc. $)$

\section{Other Memberships}

Retired members (to qualify for retired status, member must have 15 years membership in the Institute $) *(\$ 2.49$ G.S.T. inc. $)$

Student Members *(\$1.31 G.S.T. inc.)

Sustaining Individuals (CIF/IFC Members)

Sustaining Corporate $*(\$ 4.98$ G.S.T. inc.)

Upon written application, spousal members of Active Members may have the dues of one reduced by an amount determined annually. Spousal members are members of the same Section who are living together as spouses and using the same mailing address.

The Institute year runs from July 1 to June 30. Applications dated after January 1, 1992 will be charged half dues for that Institute year. Applications dated after April 1st will be charged NO DUES for that Institute year.

Section dues are in addition and range from $\$ 5.00$ to $\$ 30.00$ per Institute year.

*Note: The portion of membership which covers the cost of the Forestry Chronicle is subject to G.S.T. For tax purposes, this cost is calculated on $\$ 38.00$ which is $\$ 2.49$ G.S.T. (except Student rate of $\$ 20.00 @ \$ 1.31$ G.S.T.)

\section{Change of Address}

Date Section

Surname first - no titles

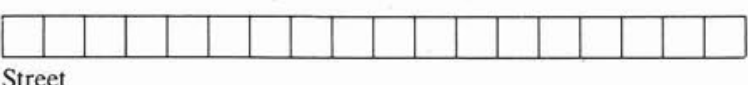

Street

City and Province

Postal Code

\section{Changement d'adresse}

Date Section

Prénom en avant - pas de titres

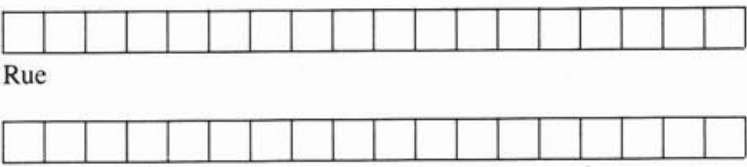

Ville et Province

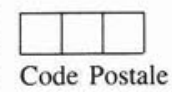

